This article is licensed under the Creative Commons Attribution-NonCommercial 4.0 International License (CC BY-NC) (http://www.karger.com/Services/OpenAccessLicense). Usage and distribution for commercial purposes requires written permission.

\title{
Palliative Endoscopic Ultrasound Biliary Drainage for Advanced Malignant Biliary Obstruction: Should It Replace the Percutaneous Approach?
}

\author{
C. Rinaldi A. Lesmana ${ }^{a, b}$ Rino A. Gani ${ }^{b}$ Irsan Hasan ${ }^{b}$ \\ Andri Sanityoso Sulaiman ${ }^{b}$ Khek Yu Hoc $^{c}$ Vinay Dhir ${ }^{d, e}$ \\ Laurentius A. Lesmana ${ }^{a}$
}

a Digestive Disease and Gastrointestinal Oncology Center, Medistra Hospital,

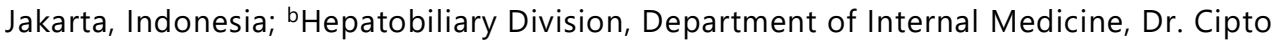
Mangunkusumo National General Hospital, Medical Faculty Universitas Indonesia, Jakarta, Indonesia; 'Division of Gastroenterology, Department of Medicine, National University Hospital, Singapore, Singapore; ${ }^{d}$ Department of Gastroenterology and Endoscopy, SL Raheja Hospital, A Fortis Associate Mahim, Mumbai, India; eDepartment of Gastroenterology and Endoscopy, Asian Cancer Institute, Somaiya Ayurvihar, Mumbai, India

\section{Keywords}

Endoscopic ultrasound-guided biliary drainage · Endoscopic ultrasound-guided choledochoduodenostomy - Endoscopic retrograde cholangiopancreatography · Malignant biliary obstruction - Percutaneous transhepatic biliary drainage 


\section{Case Reports in Gastroenterology}

Case Rep Gastroenterol 2019;13:385-397

DOI: $10.1159 / 000502835$

(c) 2019 The Author(s). Published by S. Karger AG, Base www.karger.com/crg

Lesmana et al.: Palliative Endoscopic Ultrasound Biliary Drainage for Advanced Malignant Biliary Obstruction: Should It Replace the Percutaneous Approach?

\begin{abstract}
Endoscopic retrograde cholangiopancreatography (ERCP) and percutaneous transhepatic biliary drainage (PTBD) are the standard of care in malignant biliary obstruction cases. Recently, endoscopic ultrasound-guided biliary drainage (EUS-BD) has been widely used after unsuccessful ERCP. However, the patient's clinical impact of EUS-BD over PTBD is still not obvious. Therefore, this case series study aims to evaluate the clinical outcomes of patients with advanced malignant biliary obstruction who underwent EUS-BD after failed ERCP. A retrospective database study was performed between January 2016 and June 2018 in patients with advanced malignant biliary obstruction. Patients were consecutively enrolled without randomization. Treatment options consisted of ERCP and PTBD or EUS-BD if ERCP failed. Based on 144 biliary obstruction cases, 38 patients were enrolled; 24 (63.2\%) were men. The patients' mean age was $66.8 \pm 12.36$ years. The most common cause of malignant biliary obstruction was pancreatic cancer (44.7\%). Biliary drainage was achieved by ERCP (39.5\%), PTBD (39.5\%), and EUS-BD (21.1\%). The technical success rate was $86.7 \%$ by PTBD and $87.5 \%$ by EUS-BD ( $p=1.000)$, while the clinical success rate was $93.3 \%$ by PTBD and $62.5 \%$ by EUS-BD $(p=0.500)$. The median survival in patients who underwent PTBD versus those wo underwent EUS-BD was 11 versus 3 months (log-rank $p=0.455$ ). In conclusion, there is no significant advantage of EUS-BD when compared to PTBD in terms of clinical success and survival benefit in advanced malignant biliary obstruction.

(C) 2019 The Author(s)

Published by S. Karger AG, Basel
\end{abstract}

\title{
Introduction
}

Advanced malignant biliary obstruction remains a challenging clinical situation for most gastroenterologists since it needs an urgent decision and prompt management. Palliative decompression by biliary drainage is the primary goal when curative resection is no longer feasible due to local invasion and metastasis. For many years, treatment options have been largely depending on endoscopic retrograde cholangiopancreatography (ERCP) and percutaneous transhepatic biliary drainage (PTBD) [1, 2]. Initial ERCP is the standard of care for biliary drainage, while PTBD is usually performed after a failed ERCP procedure. Biliary drainage by ERCP is the first-line option for malignant biliary obstruction and is associated with a lower adverse event rate compare to PTBD [3].

Recently, the introduction of interventional endoscopic ultrasound-guided biliary drainage (EUS-BD) has replace PTBD in many centers worldwide [4-7]. Meta-analysis showed that EUS-BD is promising as the standard treatment of choice since it is effective and safer than PTBD for biliary drainage when ERCP failed [8]. However, it is not clear whether EUS-BD has a real benefit to the patients in the palliative setting. Pancreatic cancer is the most common cause of biliary obstruction and is still the most lethal cancer in the world. It is often found in advanced state with poor prognosis and lack of satisfying treatment. Therefore, pancreatic malignancy is often a focus of study on biliary drainage management, including cost, risk, benefit, and survival $[9,10]$.

In Indonesia, which is the largest country in Southeast Asia, there have been many developments in the field of endoscopy. Recently, interventional or therapeutic endoscopic ultrasound (EUS) was offered as part of palliative management in patients with malignant biliary 


\section{Case Reports in Gastroenterology}

Case Rep Gastroenterol 2019;13:385-397

DOI: $10.1159 / 000502835$

(c) 2019 The Author(s). Published by S. Karger AG, Basel www.karger.com/crg

Lesmana et al.: Palliative Endoscopic Ultrasound Biliary Drainage for Advanced Malignant Biliary Obstruction: Should It Replace the Percutaneous Approach?

obstruction, but there is still debate with regards to the cost and availability issue, especially in more advanced stage of the disease. This study is our first report based on our real clinical practice and experience in a private referral center hospital for hepatopancreatobiliary disorders. The aim of this study was to evaluate the clinical outcomes of EUS-BD in patients with advanced malignant biliary obstruction.

\section{Methods}

\section{Study Design and Subjects}

A retrospective (historical cohort) study was done at the Digestive Disease and Gastrointestinal Oncology Center, Medistra Hospital, Jakarta between January 2016 and June 2018. Subjects were selected from adult patients with obstructive jaundice with malignant etiology, indicative for ERCP procedure. PTBD and EUS-BD were performed after ERCP failed cannulation.

All patients underwent initial abdominal imaging studies with ultrasound (US), magnetic resonance cholangiopancreatography, or EUS before the therapeutic procedure was initiated.

Diagnosis of cancer was based on cytopathology examination specimens in patients who agreed to undergo EUS biopsy (fine-needle aspiration [FNA]); in patients who did not undergo biopsy it was established by imaging studies (magnetic resonance cholangiopancreatography) combined with significantly increased tumor markers (CA19-9). The result of cytopathology was positive in all cases.

ERCP and PTBD procedures were performed by three senior gastroenterohepatologists; two of them have more than 30 years' experience (L.A.L., R.A.G.), while the other one has more than 10 years' experience (C.R.A.L.).

\section{EUS-BD Procedure}

EUS-BD was performed by a senior gastroenterohepatologist (C.R.A.L.) who has experience with more than 200 diagnostic EUS procedures and more than 150 EUS-FNA procedures (C.R.A.L.). In most cases the process was supervised by an experienced interventional endosonologist (K.Y.H. or V.D.). The EUS equipment used was an Olympus JF UCT 180 EUS scope which was connected to a high-end US equipment (Aloka IPF-1701C, Tokyo, Japan). The technique used for biliary drainage was EUS-guided choledochoduodenostomy (CDS). A 19-G needle (Echo Tip, Wilson-Cook) is inserted transduodenally into the bile duct under EUS guidance. Bile is aspirated and contrast medium is injected into the bile duct for cholangiography. A 450-cm-long, 0.035-inch guidewire (METII-35-480, Wilson-Cook) was inserted through the $19-G$ needle into the bile duct. The choledochoduodenal fistula was dilated using a biliary catheter for dilation (Soehendra biliary dilator; Wilson-Cook) or a 6-F cystostome (Endoflex Company). The Hanaro lumen apposing metallic stent was placed through the CDS site into the extrahepatic bile duct.

Technical success refers to successful stent placement in the desired position. Clinical success indicates laboratory improvement of serum bilirubin level, i.e., decreased levels by $\geq 50 \%$ within 2 weeks after the procedure [11]. 


\section{Case Reports in Gastroenterology}

Case Rep Gastroenterol 2019;13:385-397

DOI: $10.1159 / 000502835$

(c) 2019 The Author(s). Published by S. Karger AG, Basel www.karger.com/crg

Lesmana et al.: Palliative Endoscopic Ultrasound Biliary Drainage for Advanced Malignant Biliary Obstruction: Should It Replace the Percutaneous Approach?

Data Analysis

Demography and clinical data were presented descriptively. Differences between categorical variables were analyzed using Fisher's exact test, while median differences between groups were analyzed using Mann-Whitney U test. Survival difference was tested using Kaplan-Meier survival curve with log-rank $p$. A $p$ value $<0.05$ was considered statistically significant. Statistical analyses were performed using SPSS version 17.0 for Windows (SPSS Inc., Chicago, IL, USA).

\section{Results}

\section{Characteristics of the Study Subjects}

Of 144 biliary obstruction cases, there were 38 patients with malignant biliary obstruction enrolled; 24 (63.2\%) were male patients. The patients' mean age was $66.8 \pm 12.36$ years. The most common etiology of biliary obstruction was pancreatic cancer (44.7\%), followed by cholangiocarcinoma and Klatskin tumor. Biliary drainage by ERCP only was achieved in 15 (39.5\%) cases. Other characteristics are shown in Table 1.

\section{Clinical Outcomes after PTBD and EUS-BD}

Technical and clinical success rates were not significantly different between PTBD and EUS-BD (Table 2). In patients who underwent PTBD, 2 patients with metastatic renal cell carcinoma to the pancreas (Fig. 1) and cholangiocarcinoma needed further management with rendezvous technique and internal biliary stent placement. Another 2 patients needed repeated PTBD within 3 days due to failed normalization of bilirubin levels, which were considered clinical failure.

In the EUS-BD group, the only technical failure was a patient who needed salvage percutaneous transhepatic gallbladder drainage (PTGBD) and repeated EUS-BD on the next day due to difficult dilatation of the fistula track (Fig. 2). There was no adverse event in patients who underwent PTBD, whereas 1 patient who underwent EUS-BD developed cholangitis and was conservatively managed with antibiotic therapy (Table 3).

The median survival of patients who underwent PTBD tended to be higher than that of those who underwent EUS-BD (Fig. 3). However, metastatic disease tends to be found more frequently in patients undergoing EUS-BD. Furthermore, regardless of the type of procedure, presence of metastasis was the only factor significantly associated with shorter survival ( $3 \mathrm{vs}$. 11 months; log-rank $p=0.031$ ).

\section{Discussion}

To our knowledge, this is the first study in Southeast Asia to assess the survival benefit of EUS-BD and PTBD procedures in the management of advanced malignant biliary obstruction as palliative options after ERCP failure, where medical procedural cost is still a major issue. The lower success rate of ERCP in this unit is due to the fact that most of the malignant cases were referred from another hospital with advanced stage of pancreatic cancer or large tumor size causing total distal bile duct obstruction, even though ERCP was performed in the native 


\section{Case Reports in Gastroenterology}

Case Rep Gastroenterol 2019;13:385-397

DOI: $10.1159 / 000502835$

(c) 2019 The Author(s). Published by S. Karger AG, Basel www.karger.com/crg

Lesmana et al.: Palliative Endoscopic Ultrasound Biliary Drainage for Advanced Malignant Biliary Obstruction: Should It Replace the Percutaneous Approach?

papilla. In our center, PTBD is routinely performed directly after failed ERCP by consultant gastroenterologists and not by interventional radiologists. Even though we are more experienced in PTBD, EUS-CDS was performed by a senior consultant who was already experienced in diagnostic EUS and EUS-FNA procedures, and most of the procedures were evaluated or supervised by experienced interventional endosonologist.

Currently, EUS-BD is not the first-line management of malignant biliary obstruction in Indonesia or most developing Asian countries. Many studies have shown the advantage of performing EUS-BD after a failed ERCP cannulation [12-15]. However, EUS-BD requires high levels of experience and technique as most studies were performed in highly expert centers. Furthermore, EUS-BD should be performed in institutions that are capable to do salvage procedures such as PTBD or PTGBD when it fails [16]. In our case series study, the technical success rate of EUS-CDS was quite high (87.5\%). The reported technical success rate for EUS-CDS was between 56 and 100\% [13]. EUS-CDS was the preferred method in this study because all the patients who underwent either EUS-CDS or PTBD were equally due to distal malignant biliary obstruction. A study involving 101 patients in France concluded that morbidity related to EUS$\mathrm{BD}$ is higher than that related to ERCP, but decreases with an increased learning curve. In their 7-year experience, five procedure-related deaths occurred in the first 50 patients and drop to one in the last 51 patients [17].

Repeated PTBD was needed by only 2 of 15 patients in our study due to clinical failure (decreased bilirubin levels $<50 \%$ ). After re-intervention, bilirubin levels were much more reduced in both patients. Another patient had metastatic renal cell carcinoma and was managed by PTBD followed by rendezvous technique due to problems with a dislodged catheter and patient discomfort with an external catheter. One patient with ampullary carcinoma underwent common bile duct stenting, but later developed gallbladder empyema which was not related to the stenting procedure. She then underwent PTGBD. Our study is similar to that by Lee et al. [18], who did a randomized trial comparing the impact of EUS-BD with PTBD in advanced distal malignant biliary obstruction. They showed that PTBD has similar efficacy to EUS-BD in advanced disease; however, the authors concluded that complications and re-intervention rates were higher in the PTBD group. In our study experience, we showed almost no significant complications noted in our PTBD group. This result might be different due to the fact that most of PTBD is performed by interventional radiologist in developed Asian countries and even developed Western countries. This issue has also been shown by another two studies where the authors concluded that EUS-BD showed higher clinical success rate and more complications in PTBD group. In the study by Sharaiha et al. [19], it was mentioned that EUS-BD has lower cost than PTBD, but in our country PTBD is much cheaper than EUS-BD [20]. This has been another issue which has to be considered in every country since it would have a big impact on clinical decision regarding the patient's survival.

In our patients who underwent EUS-CDS, only 1 patient needed repeated procedure due to technical failure. However, clinical failure occurred in 3 patients; 1 of them died within 10 days after the procedure due to sepsis and renal failure. One patient who developed cholangitis after EUS-BD could be managed conservatively. There was no bile leak, bleeding, or stent migration among our EUS-BD patients.

At this point, it is obvious that technical success and adverse event depends largely on the operator's skill. PTBD can be used as a bridge to a rendezvous technique that is commonly used for internal drainage metallic stent placement. The advantages of this procedure are the 


\section{Case Reports in Gastroenterology}

Case Rep Gastroenterol 2019;13:385-397

DOI: $10.1159 / 000502835$

(c) 2019 The Author(s). Published by S. Karger AG, Base www.karger.com/crg

Lesmana et al.: Palliative Endoscopic Ultrasound Biliary Drainage for Advanced Malignant Biliary Obstruction: Should It Replace the Percutaneous Approach?

ease to control bile flow through an external catheter and prevention of clogging stent. However, patient comfort and catheter dislodgment are the two main problems in daily practice. In fact, studies have shown that there is a similar comparable clinical efficacy between PTBD and EUS-BD with regards to the experience in each center [21,22]. However, in most parts of the world, PTBD should be performed by an experienced interventional radiologist. Only in some centers in Asia, including Japan and Indonesia, PTBD was pioneered and developed by interventional hepatologists.

Survival analyses showed that our EUS-BD patients tended to have shorter survival than PTBD patients. However, this could be caused by selection bias since patients who underwent EUS-BD in this study tended to have more severe disease (mostly with metastatic disease) and be of older age. In real practice, this kind of patients may prefer EUS-BD to PTBD for its convenience. Although we are aware of the selection bias, it could not be avoided since patients were not randomized due to patient preference after consent. However, our study results showed the real situation in clinical practice.

Survival benefit was not known, and it assumed that biliary drainage will prolong a patient's life. Our previous report showed that pancreatic cancer is the most common cancer referred for EUS imaging [23], and many of the patients were already presented in advanced stage of disease. Metastatic disease might significantly reduce survival regardless of treatment choice. Our current study confirmed that presence of metastasis is the only significant factor to predict survival. Chemotherapy was administered by a medical oncologist based on standard management and indication.

A recent local study from the National Teaching Hospital in Jakarta showed that ERCP has no survival advantage when compared to PTBD in patients with advanced malignant biliary obstruction [24]. This was supported by another study showing that there was a significant increase in inflammatory markers in ERCP patients compared to PTBD patients [25]. The results of these studies were considered to be due to the use of contrast agents in ERCP as the primary cause. On the contrary, in this teaching hospital, PTBD is performed under US guidance, not by fluoroscopy and contrast agent. Procedures involving manipulation of the bile duct and contrast agent filling may increase the risk of epithelial injury and cause bile duct inflammation.

There are some limitations of our study. First, it was not designed as a prospective randomized trial between two groups of patients or a head-to-head comparison study. However, our case series study showed the real-life situation in daily practice. Second, this study might be considered to be underpowered due to the small sample size. However, statistical analyses were not meant to distinguish the efficacy of PTBD versus EUS-BD, since both procedures were known to be equally effective for biliary decompression. Rather, they were performed to give some insight into the clinical performance of the new technique (EUS-BD) over the routine procedure (PTBD). The complexity of the patients with malignant biliary obstruction and ethical considerations did not made it easy to design a head-to-head comparison of EUS$\mathrm{BD}$ and PTBD in the private setting. The reason is because it is probably unethical to do in reallife clinical practice where patients have the right to make a choice after explanation with regards to the stage of the disease.

The role of EUS-BD to replace PTBD or considering it as the primary procedure of choice in advanced malignant biliary obstruction is still questionable since it cannot prolong survival among metastatic pancreatic cancer patients. 
In conclusion, advanced malignant biliary obstruction is still a challenging problem in clinical practice. Altogether, the cost, risk, and survival benefit are the most important things to be considered in clinical practice before choosing an option. We suggest that in patients with poor prognosis and possibly distant metastasis, PTBD might be considered the first procedure of choice. However, in cases without metastasis and possibly with better survival with chemotherapy, EUS-BD can be the first choice after failed ERCP cannulation.

\section{Acknowledgement}

The authors would like to thank Dr. Levina S. Pakasi from Verum Medical Research who was consulted for the statistical analyses and English editing of the manuscript.

\section{Statement of Ethics}

This study was approved by the Ethics Committee for Health Studies, Medistra Hospital, Jakarta with a letter on May 11, 2018 (No. 001/KEPKM/V/2018). The study protocol conforms to the ethical guidelines of the 1975 Declaration of Helsinki as reflected in a priori approval by the institution's human research committee. Written consent was obtained from the patients and/or their families for publishing their imaging results.

\section{Disclosure Statement}

The authors declare no conflict of interest regarding this study.

\section{Author Contributions}

C.R.A. Lesmana provided the idea and design the study, collected the patient database, analyzed the data, and wrote the manuscript. R.A. Gani, I. Hasan, and A.S. Sulaiman were involved in patient database collection and data analysis. K.Y. Ho and V. Dhir supervised the past procedures and involved in manuscript idea and correction. L.A. Lesmana was involved in database analysis and manuscript preparation.

\section{References}

1 Lorenz JM. Management of malignant biliary obstruction. Semin Intervent Radiol. 2016 Dec;33(4):259-67.

2 Boulay BR, Birg A. Malignant biliary obstruction: from palliation to treatment. World J Gastrointest Oncol. 2016 Jun;8(6):498-508.

3 Inamdar S, Slattery E, Bhalla R, Sejpal DV, Trindade AJ. Comparison of adverse events for endoscopic vs percutaneous biliary drainage in the treatment of malignant biliary tract obstruction in an inpatient national cohort. JAMA Oncol. 2016 Jan;2(1):112-7. 


\section{Case Reports in Gastroenterology}

Case Rep Gastroenterol 2019;13:385-397

DOI: $10.1159 / 000502835$

(c) 2019 The Author(s). Published by S. Karger AG, Base www.karger.com/crg

Lesmana et al.: Palliative Endoscopic Ultrasound Biliary Drainage for Advanced Malignant Biliary Obstruction: Should It Replace the Percutaneous Approach?

4 Sarkaria S, Sundararajan S, Kahaleh M. Endoscopic ultrasonographic access and drainage of the common bile duct. Gastrointest Endosc Clin N Am. 2013 Apr;23(2):435-52.

5 Kim YS, Gupta K, Mallery S, Li R, Kinney T, Freeman ML. Endoscopic ultrasound rendezvous for bile duct access using a transduodenal approach: cumulative experience at a single center. A case series. Endoscopy. 2010 Jun;42(6):496-502.

6 Hara K, Yamao K, Niwa Y, Sawaki A, Mizuno N, Hijioka S, et al. Prospective clinical study of EUS-guided choledochoduodenostomy for malignant lower biliary tract obstruction. Am J Gastroenterol. 2011 Jul;106(7):1239-45.

7 Dhir V, Bhandari S, Bapat M, Maydeo A. Comparison of EUS-guided rendezvous and precut papillotomy techniques for biliary access (with videos). Gastrointest Endosc. 2012 Feb;75(2):354-9.

8 Baniya R, Upadhaya S, Madala S, Subedi SC, Shaik Mohammed T, Bachuwa G. Endoscopic ultrasound-guided biliary drainage versus percutaneous transhepatic biliary drainage after failed endoscopic retrograde cholangiopancreatography: a meta-analysis. Clin Exp Gastroenterol. 2017 Apr;10:67-74.

9 Huang P, Zhang H, Zhang XF, Lv W, Lou S. Comparison of endoscopic ultrasonography guided biliary drainage and percutaneous transhepatic biliary drainage in the management of malignant obstructive jaundice after failed ERCP. Surg Laparosc Endosc Percutan Tech. 2017 Dec;27(6):e127-31.

10 Kosmidis C, Sapalidis K, Kotidis E, Mixalopoulos N, Zarogoulidis P, Tsavlis D, et al. Pancreatic cancer from bench to bedside: molecular pathways and treatment options. Ann Transl Med. 2016 May;4(9):165.

11 Lesmana CR, Gani RA, Lesmana LA. Non-alcoholic fatty pancreas disease, pancreatic cancer, and impact of endoscopic ultrasound examination on screening and surveillance. EMJ Gastroenterol. 2017;6(1):69-74.

12 Park DH, Jang JW, Lee SS, Seo DW, Lee SK, Kim MH. EUS-guided biliary drainage with transluminal stenting after failed ERCP: predictors of adverse events and long-term results. Gastrointest Endosc. 2011 Dec;74(6): 1276-84.

13 Iwashita T, Lee JG, Shinoura S, Nakai Y, Park DH, Muthusamy VR, et al. Endoscopic ultrasound-guided rendezvous for biliary access after failed cannulation. Endoscopy. 2012 Jan;44(1):60-5.

14 Moole H, Bechtold ML, Forcione D, Puli SR. A meta-analysis and systematic review: success of endoscopic ultrasound guided biliary stenting in patients with inoperable malignant biliary strictures and a failed ERCP. Medicine (Baltimore). 2017 Jan;96(3):e5154.

15 Makmun D, Fauzi A, Abdullah M, Syam AF. The role of EUS-BD in the management of malignant biliary obstruction: the Indonesian perspective. Diagn Ther Endosc. 2017;2017:4856276.

16 Ikeuchi N, Itoi T. Endoscopic ultrasonography-guided biliary drainage: an alternative to percutaneous transhepatic puncture. Gastrointest Interv. 2015;4(1):31-9.

17 Poincloux L, Rouquette O, Buc E, Privat J, Pezet D, Dapoigny M, et al. Endoscopic ultrasound-guided biliary drainage after failed ERCP: cumulative experience of 101 procedures at a single center. Endoscopy. 2015 Sep;47(9):794-801.

18 Lee TH, Choi JH, Park H, Song TJ, Kim DU, Paik WH, et al. Similar efficacies of endoscopic ultrasound-guided transmural and percutaneous drainage for malignant distal biliary obstruction. Clin Gastroenterol Hepatol. 2016 Jul;14(7):1011-1019.e3.

19 Sharaiha RZ, Kumta NA, Desai AP, DeFilippis EM, Gabr M, Sarkisian AM, et al. Endoscopic ultrasound-guided biliary drainage versus percutaneous transhepatic biliary drainage: predictors of successful outcome in patients who fail endoscopic retrograde cholangiopancreatography. Sur Endosc. 2016 Dec;30(12):5500-5.

20 Téllez-Ávila FI, Herrera-Mora D, Duarte-Medrano G, Lopez-Arce G, Lindoro-Barraza D, Casanova I, et al. Biliary drainage in patients with failed ERCP: percutaneous versus EUS-guided drainage. Surg Laparosc Endosc Percutan Tech. 2018 Jun;28(3):183-7.

21 Bill JG, Darcy M, Fujii-Lau LL, Mullady DK, Gaddam S, Murad FM, et al. A comparison between endoscopic ultrasound-guided rendezvous and percutaneous biliary drainage after failed ERCP for malignant distal biliary obstruction. Endosc Int Open. 2016 Sep;4(9):E980-5.

22 Artifon EL, Aparicio D, Paione JB, Lo SK, Bordini A, Rabello C, et al. Biliary drainage in patients with unresectable, malignant obstruction where ERCP fails: endoscopic ultrasonography-guided choledochoduodenostomy versus percutaneous drainage. J Clin Gastroenterol. 2012 Oct;46(9):768-74.

23 Lesmana CR, Gani RA, Lesmana LA. Non-alcoholic fatty pancreas disease as a risk factor for pancreatic cancer based on endoscopic ultrasound examination among pancreatic cancer patients: a single-center experience. JGH Open. 2017 Dec 23;2(1):4-7.

24 Kurniawan J, Hasan I, Gani RA, Simadibrata M. Mortality-related factors in patients with malignant obstructive jaundice. Acta Med Indones. 2016 Oct;48(4):282-8.

25 Sabarudin A, Gani RA, Abdullah M, Rumende CM. Changes in tumor necrosis factor alpha and interleukin 6 levels in patients with obstructive jaundice due to pancreatobiliary cancer who underwent biliary drainage. Indones J Gastroenterol Hepatol Dig Endosc. 2016;17(2):93-8. 


\section{Case Reports in Gastroenterology}

Case Rep Gastroenterol 2019;13:385-397

Lesmana et al.: Palliative Endoscopic Ultrasound Biliary Drainage for Advanced Malignant

Biliary Obstruction: Should It Replace the Percutaneous Approach?

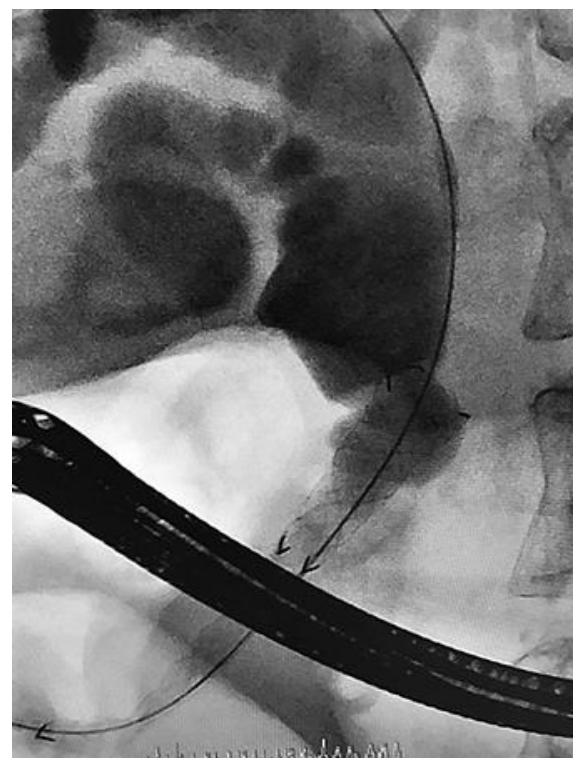

Fig. 1. Patient with metastatic renal cell carcinoma which caused distal biliary obstruction who underwent rendezvous technique (from PTBD) for metallic biliary stent placement.
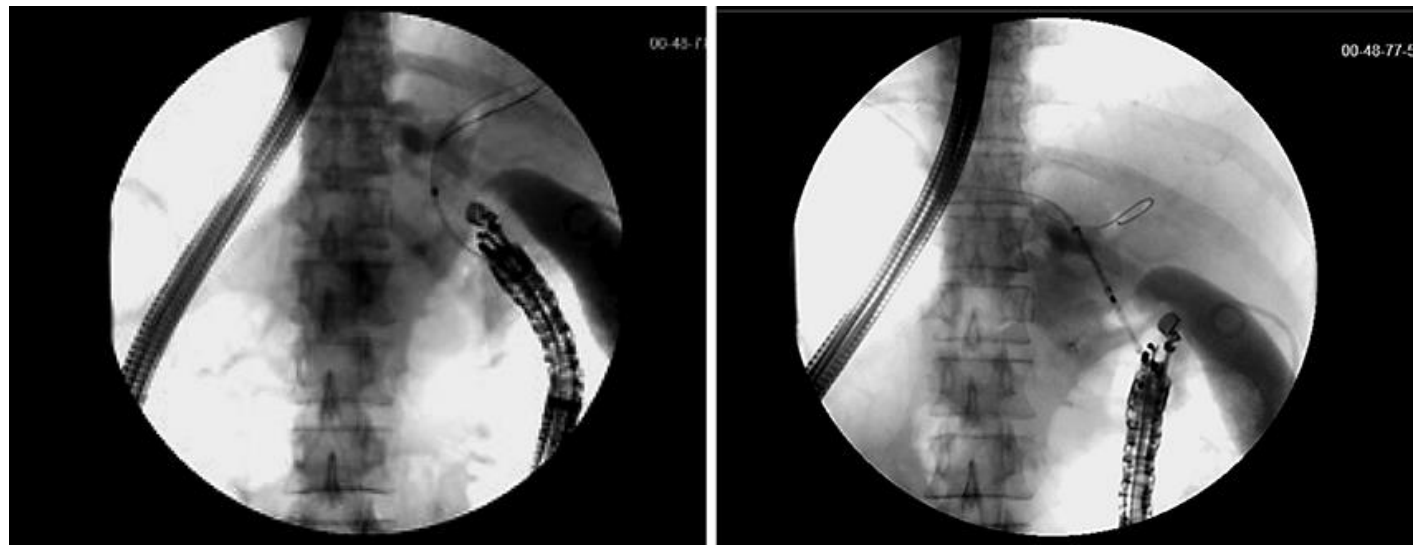

Fig. 2. Pancreatic cancer patient who underwent salvage PTGBD due to the difficulty of fistula track dilatation and repeated EUS-CDS. 


\section{Case Reports in Gastroenterology}

Case Rep Gastroenterol 2019;13:385-397

(C) 2019 The Author(s). Published by S. Karger AG, Basel www.karger.com/crg

Lesmana et al: Palliative Endoscopic Ultrasound Biliary Drainage for Advanced Malignant

Biliary Obstruction: Should It Replace the Percutaneous Approach?

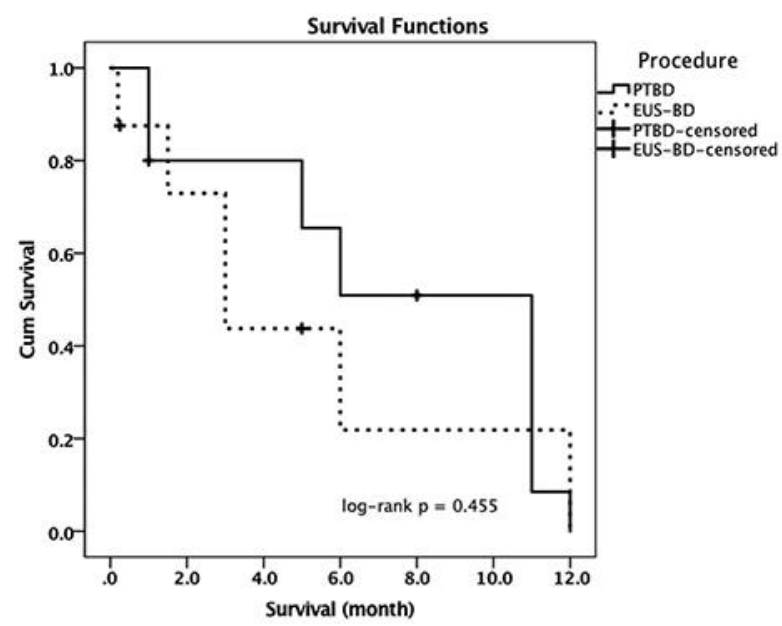

Fig. 3. Kaplan-Meier survival curves of patients who underwent PTBD and EUS-BD. 


\section{Case Reports in Gastroenterology}

Table 1. Characteristics of the study subjects $(n=38)$

\begin{tabular}{|c|c|c|}
\hline Characteristic & Mean (SD) & $n(\%)$ \\
\hline \multicolumn{3}{|l|}{ Sex } \\
\hline Male & & $24(63.2)$ \\
\hline Female & & $14(36.8)$ \\
\hline Age, years & $66.8(12.36)$ & \\
\hline Body mass index, $\mathrm{kg} / \mathrm{m}^{2}$ & $22.3(3.84)$ & \\
\hline \multicolumn{3}{|l|}{ Nutrition status } \\
\hline Underweight & & $8(21.1)$ \\
\hline Normal weight & & $14(36.8)$ \\
\hline Overweight & & $9(23.7)$ \\
\hline Obese & & 7 (18.4) \\
\hline \multicolumn{3}{|l|}{ Primary disease } \\
\hline Pancreatic tumor & & $17(44.7)$ \\
\hline Cholangiocarcinoma & & $7(18.4)$ \\
\hline Klatskin tumor & & $4(10.5)$ \\
\hline Cancer of the ampulla of Vater & & $4(10.5)$ \\
\hline Duodenal cancer & & $2(5.3)$ \\
\hline Gastric cancer & & $1(2.6)$ \\
\hline Gallbladder cancer & & $1(2.6)$ \\
\hline Liver tumor & & $1(2.6)$ \\
\hline Renal cancer metastasized to the pancreas & & $1(2.6)$ \\
\hline Total bilirubin, mg/dL & $12.9(7.80)$ & \\
\hline Direct bilirubin & $11.5(7.56)$ & \\
\hline Gamma glutaryl transferase, U/L & $456.5(411.48)$ & \\
\hline Alkaline phosphatase, U/L & $360.0(261.38)$ & \\
\hline \multicolumn{3}{|l|}{ Primary procedure } \\
\hline ERCP & & $15(39.5)$ \\
\hline PTBD & & $15(39.5)$ \\
\hline EUS-BD & & $8(21.1)$ \\
\hline
\end{tabular}




\section{Case Reports in Gastroenterology}

Table 2. Clinical comparison between patients who underwent PTBD and EUS-BD

\begin{tabular}{|c|c|c|c|}
\hline Characteristic & $\begin{array}{l}\text { PTBD } \\
(n=15)\end{array}$ & $\begin{array}{l}\text { EUS-BD } \\
(n=8)\end{array}$ & $p$ value \\
\hline Male sex & $9(60 \%)$ & $6(75.0 \%)$ & $0.657 \mathrm{a}$ \\
\hline Median age (range) & $70(45-87)$ & $72.5(44-83)$ & $0.419 \mathrm{~b}$ \\
\hline Pancreatic tumor & $7(46.7 \%)$ & $6(75.0 \%)$ & $0.379 a$ \\
\hline Presence of metastatic disease & $3(20 \%)$ & $4(50 \%)$ & $0.182^{\mathrm{a}}$ \\
\hline Technical success rate & $13(86.7 \%)$ & $7(87.5 \%)$ & $1.000^{\mathrm{a}}$ \\
\hline Median bilirubin reduction, \% (range) ${ }^{\mathrm{d}}$ & $76(34-84)$ & $66(34-79)$ & $0.119^{b}$ \\
\hline Clinical success rate & $14(93.3 \%)$ & $5(62.5 \%)$ & $0.500^{\mathrm{a}}$ \\
\hline Median survival, months & 11 & 3 & $0.455^{c}$ \\
\hline
\end{tabular}

a Fisher's exact test. b Mann-Whitney U test. c Log-rank test. d Except for 2 cases with increased bilirubin within 2 weeks after procedure. ${ }^{e}$ Includes 1 case after repeated EUS-BD. 


\section{Case Reports in Gastroenterology}

\begin{tabular}{l|l}
\hline Case Rep Gastroenterol 2019;13:385-397 \\
\hline DOI: 10.1159/000502835 & $\begin{array}{l}\text { @ 2019 The Author(s). Published by S. Karger AG, Basel } \\
\text { www.karger.com/crg }\end{array}$ \\
\hline
\end{tabular}
www.karger.com/crg

Lesmana et al.: Palliative Endoscopic Ultrasound Biliary Drainage for Advanced Malignant Biliary Obstruction: Should It Replace the Percutaneous Approach?

Table 3. Clinical characteristics of patients who underwent PTBD $(n=15)$ or EUS-BD $(n=8)$

\begin{tabular}{|c|c|c|c|c|c|c|}
\hline $\begin{array}{l}\text { Patient } \\
\text { No. }\end{array}$ & Sex & $\begin{array}{l}\text { Age, } \\
\text { years }\end{array}$ & Primary tumor & Metastasis & Re-intervention & $\begin{array}{l}\text { Survival, } \\
\text { months }\end{array}$ \\
\hline \multicolumn{7}{|c|}{ Patients who underwent PTBD } \\
\hline 1 & $\mathrm{~F}$ & 73 & pancreas & no & yes & 12 \\
\hline 2 & $\mathrm{~F}$ & 76 & pancreas & no & no & $<12$ \\
\hline 3 & $\mathrm{~F}$ & 76 & pancreas & no & no & $<12$ \\
\hline 4 & M & 48 & pancreas & no & no & 6 \\
\hline 5 & $\mathrm{~F}^{1}$ & 65 & ampulla of Vater & no & no & 8 (alive) \\
\hline 6 & M & 45 & pancreas & no & no & $<12$ \\
\hline 7 & M & 87 & duodenal & yes & no & $<6$ \\
\hline 8 & M & 71 & gaster & yes & yes & $<6$ \\
\hline 9 & M & 51 & gallbladder & yes & no & 6 \\
\hline 10 & M & 83 & cholangiocarcinoma & no & no & 1 \\
\hline 11 & $\mathrm{M}^{2}$ & 60 & kidney & yes & no & 1 (alive) \\
\hline 12 & $\mathrm{~F}$ & 56 & pancreas & no & no & $<12$ \\
\hline 13 & M & 70 & ampulla of Vater & no & no & 1 \\
\hline 14 & $\mathrm{~F}$ & 79 & cholangiocarcinoma & no & no & 1 \\
\hline 15 & M & 55 & pancreas & no & no & $<12$ \\
\hline \multicolumn{7}{|c|}{ Patients who underwent EUS-BD } \\
\hline 1 & $\mathrm{~F}$ & 83 & pancreas & yes & no & $<3$ \\
\hline 2 & M & 78 & pancreas & no & no & 5 (alive) \\
\hline 3 & M & 73 & pancreas & yes & no & 6 \\
\hline 4 & $\mathrm{~F}$ & 71 & pancreas & yes & no & 3 \\
\hline 5 & $\mathrm{M}^{3}$ & 44 & pancreas & no & yes & 12 \\
\hline 6 & M & 67 & duodenal & yes & no & 3 \\
\hline 7 & M & 72 & ampulla of Vater & no & no & $<1$ \\
\hline 8 & M & 81 & pancreas & no & yes & $<1$ (alive) \\
\hline
\end{tabular}

1 Previously underwent CBD stenting/developed gallbladder empyema $\rightarrow$ underwent percutaneous transhepatic gallbladder drainage (PTGBD). ${ }^{2}$ Underwent PTBD $\rightarrow$ rendezvous. ${ }^{3}$ Previously failed EUS-BD then underwent salvage PTGBD $\rightarrow$ repeated EUS-BD. 